\title{
Base excision repair synthesis of DNA containing 8-oxoguanine in Escherichia coli
}

\author{
Yun-Song Lee ${ }^{1,3}$ and Myung-Hee Chung ${ }^{2}$ \\ ${ }^{1}$ Division of Pharmacology \\ Department of Molecular and Cellular Biology \\ Sungkyunkwan University School of Medicine \\ Suwon 440-746, Korea \\ ${ }^{2}$ Department of Pharmacology \\ Seoul National University College of Medicine \\ Jongno-gu, Seoul 110-799, Korea \\ ${ }^{3}$ Corresponding author: Tel, 82-31-299-6190; \\ Fax, 82-31-299-6209; E-mail, yslee@skku.ac.kr
}

\section{Accepted 29 March 2003}

Abbreviations: 8-oxo-G, 8-oxo-7,8-dihydroguanine; Fapy, 2,6-dihydroxy-5N-formamidopyrimidine; FPG, Fapy-DNA glycosylase; BER, base excision repair; AP, apuriniclapyrimidinic; dRPase, deoxyribophosphatase

\begin{abstract}
8-0x0-7,8-dihydroguanine (8-0xo-G) in DNA is a mutagenic adduct formed by reactive oxygen species. In Escherichia coli, 2,6-dihydroxy-5N-formamidopyrimidine (Fapy)-DNA glycosylase (Fpg) removes this mutagenic adduct from DNA. In this report, we demonstrate base excision repair (BER) synthesis of DNA containing 8-0xo-G with Fpg in vitro. Fpg cut the oligonucleotide at the site of 8-oxo-G, producing one nucleotide gap with $3^{\prime}$ and 5' phosphate termini. Next, 3' phosphatase(s) in the supernatant obtained by precipitating a crude extract of $E$. coli with $40 \%$ ammonium sulfate, removed the 3' phosphate group at the gap, thus exposing the 3' hydroxyl group to prime DNA synthesis. DNA polymerase and DNA ligase then completed the repair. These results indicate the biological significance of the glycosylase and apurinicl apyrimidinic (AP) lyase activities of Fpg, in concert with 3' phosphatase(s) to create an appropriately gapped substrate for efficient BER synthesis of DNA containing 8-0xo-G.
\end{abstract}

Keywords: DNA repair; Escherichia coli; mutagenesis; oxiative stress; reactive oxygen species; phosphatases

\section{Introduction}

8-oxo-7,8-dihydroguanine (8-oxo-G) in DNA is a mutagenic adduct formed by reactive oxygen species (Kasai and Nishimura, 1984). As a structural preference, adenine is frequently incorporated into opposite template 8-oxo-G (Shibutani et al., 1991), and 8oxo-dGTP is incorporated into opposite template $d A$ during DNA synthesis (Cheng et al., 1992). Thus, unrepaired, these mismatches lead to GT and AC transversions, respectively (Grollman and Morya, 1993).

In Escherichia coli, several DNA repair enzymes, preventing mutagenesis by 8-oxo-G, are known as the GO system (Michaels et al., 1992). The GO system consists of MutT (8-oxo-dGTPase), MutM (2,6-dihydroxy-5N-formamidopyrimidine (Fapy)-DNA glycosylase, $\mathrm{Fpg}$ ) and MutY (adenine-DNA glycosylase). 8-oxoGTPase prevents incorporation of 8-oxo-dGTP into DNA by degrading 8-oxo-dGTP. Adenine-DNA glycosylase preferentially excises A paired with 8-oxo-G, restoring the 8-oxo-G:C pair, a substrate for Fpg.

Fpg has multiple enzymatic activities. Through its glycosylase activity, it removes Fapy and 8-oxo-G from oxidatively damaged DNA (Tchou et al., 1991), and it has apurinic/apyrimidinic (AP) lyase activity to remove the AP site by successive $\beta$ - and $\delta$-elimination mechanisms, which results in a single nucleotide gap with 3 ' and 5' phosphate termini at the gap (Tchou et al., 1991; Bhagwat and Gerlt, 1996). In addition, it has 5' deoxyribophosphatase (dRPase) activity to remove 5' deoxyribophosphate from DNA strands (Graves et al., 1992).

Various kinds of DNA glycosylases specific to each of the modified bases have been known to initiate base excision repair (BER) DNA synthesis by removing the modified DNA bases. In the case of the DNA glycosylases with AP lyase activity to induce $\beta$ - and $\delta$-elimination, short patch BER synthesis has been proposed (Memisoglu and Samson, 2000). Initially, the glycosylases produce one nucleotide gap with 3 ' and 5' phosphate termini at the gap through glycosylase and AP lyase activities. Then, 3' phosphatase removes the $3^{\prime}$ terminal phosphate at the gap, providing a 3' prime end for the insertion of a single nucleotide. Thereafter, DNA polymerase inserts one nucleotide and DNA ligase seals the nick to complete short patch BER DNA synthesis. Here, we demonstrate in vitro short patch BER synthesis of DNA containing 8-oxo-G by Fpg based on this proposed repair model. 


\section{Material and Methods}

\section{Materials}

Exonuclease III-deficient E. coli (BW 9053) was used for the purification of $\mathrm{Fpg}$ and the AS 40/100 fraction. Purification procedures were performed using HPLCs (Model 302 pump, Model 811B gradient mixer, Model 115 UV detector; Gilson, France), and a conventional gel filtration chromatography $(2.6 \times 100 \mathrm{~cm}$ column packed with Sephacryl S-200; Amersham Pharmacia, UK). Columns for phenyl HPLC (Phenyl-5PW, 21.5x $150 \mathrm{~mm}$ ), DEAE HPLC (DEAE-5PW, 21.5×150 mm), heparin affinity HPLC (Heparin-5PW, $7.5 \times 75 \mathrm{~mm}$ ) and hydroxylapatite HPLC (HA 1000, 7.5×75 mm) were from Toyo Soda (Japan). Radioactive nucleotides were obtained from Amersham Pharmacia (UK) or NEN (Boston, MA). T4 polynucleotide kinase and 3 ' end-labeling kits and nucleotides were from Roche (Germany). T4 DNA polymerase, T4 DNA ligase and gene 32 product were from BioRad (Hercules, CA). All other chemicals were from Sigma (St. Louis, MO).

\section{Preparation of enzymes}

Fpg was purified chromatographically. Briefly, from the crude extract of $E$. coli deprived of nucleic acids by $0.8 \%$ streptomycin, homogenous Fpg was obtained by fractionation with ammonium sulfate, phenyl HPLC, DEAE HPLC, gel filtration, phenyl HPLC, heparin affinity HPLC and hydroxylapatite HPLC applied sequentially. One unit of enzyme activity was defined as the activity required to cleave $1 \mathrm{fmol}$ of double stranded DNA containing $8-0 \times 0-G$ at $37^{\circ} \mathrm{C}$ for $60 \mathrm{~min}$ (Chung et al., 1991)

AS 40/100 fraction: ammonium sulfate was added to a final concentration of $40 \%$ to the crude extract devoid of nucleic acids with stirring at $4^{\circ} \mathrm{C}$ for $1 \mathrm{~h}$. After centrifugation at $25,000 \mathrm{~g}$ for $30 \mathrm{~min}$, the supernatant was dialyzed against a buffer $(50 \mathrm{mM}$ Tris- $\mathrm{HCl}, \mathrm{pH} 7.5,0.5 \mathrm{mM}$ EDTA, $0.2 \mathrm{mM}$ dithiothreitol and $10 \%$ glycerol). The dialysate was centrifuged and the supernatant (AS 40/100 fraction) was used in the experiment.

\section{Labeling of substrate double-stranded DNA and other oligonucleotides}

For BER synthesis, 21-mer (5' CAGCCAATCAGT$\underline{G}^{\text {oxo }}$ CACCATCC 3'; $\underline{G}^{\text {oxo }}=8-0 \times 0-G$ ) was used (a kind gift from Dr. Kasai at the University of Occupational and Environmental Health, Japan). The 21-mer oligonucleotide was labeled at the $5^{\prime}$ end with $\left[\gamma^{32} \mathrm{P}\right]$ ATP and T4 polynucleotide kinase, and then annealed to its complementary strand as described previously (Chung et al., 1991). To confirm incision site $3^{\prime}$ to 8-oxo-G by Fpg, 46-mer oligonucleotide (5' CAGCCA-
ATCAGTG ${ }^{0 \times 0}$ CACCATCCCGGGTCGTTTTACAACGTCGTGACT 3') was labeled at the $3^{\prime}$ end with a $3^{\prime}$ end-labeling kit and $\left[\alpha-{ }^{32} \mathrm{P}\right]$ cordycepin ATP, and annealed to its complementary oligonucleotide as described previously (Chung et al., 1991). For identification of the $3^{\prime}$ or $5^{\prime}$ termini at the incision site by Fpg or the AS 40/100 fraction, single-stranded $5^{\prime}$ endlabeled oligonucleotide (21-mer) or single-stranded $3^{\prime}$ end-labeled oligonucleotide (46-mer) was incubated with piperidine at $90^{\circ} \mathrm{C}$ for $30 \mathrm{~min}$ (Chung et al., 1992). To confirm removal of $3^{\prime}$ terminal phosphate, synthetic 12-mer oligonucleotide without $3^{\prime}$ terminal phosphate was labeled at 5 ' end.

\section{Enzyme reactions}

Formation of a single nucleotide gap by Fpg

Fpg or the AS 40/100 fraction was incubated with 0.4 pmol of $5^{\prime}$ end-labeled or $3^{\prime}$ end-labeled substrate DNA in $50 \mu$ of a reaction mixture containing $50 \mu \mathrm{M}$ Tris- $\mathrm{HCl}, \mathrm{pH} 7.4,50 \mathrm{mM} \mathrm{KCl}$ and $2 \mathrm{mM}$ EDTA at $25^{\circ} \mathrm{C}$.

Removal of $3^{\prime}$ terminal phosphate by the AS40/100 fraction

To a reaction mixture containing 0.4 pmol of substrate 21-mer DNA treated with 400 units of $\mathrm{Fpg}$ at $25^{\circ} \mathrm{C}$ for $90 \mathrm{~min}, 200 \mu \mathrm{g}$ of AS 40/100 fraction was added, and the mixture was incubated at $25^{\circ} \mathrm{C}$ for $90 \mathrm{~min}$. $50 \mu$ of distilled water and $100 \mu$ of phenol:chloroform (1:1) were then added, vigorously mixed and centrifuged at $12,000 \mathrm{~g}$ for $5 \mathrm{~min}$, and $50 \mu \mathrm{l}$ of the supernatant was then collected and dried using a vacuum concentrator (Savant, NY).

Insertion of $d G$ by DNA polymerase and sealing of the nick by DNA ligase

The above 21 mer substrate DNA gapped by successive treatment with Fpg and the AS 40/100 fraction was incubated with 1 unit of T4 DNA polymerase, 3 units of T4 DNA ligase, $50 \mathrm{mg}$ of gene 32 product, $5 \mathrm{mM}$ of dNTPs and $10 \mathrm{mM} \mathrm{ATP}$ in $100 \mu \mathrm{l}$ of a reaction buffer containing $5 \mathrm{mM} \mathrm{MgCl}_{2}, 2 \mathrm{mM}$ dithiothreitol and $100 \mathrm{mM}$ Tris- $\mathrm{HCl}$, at $4^{\circ} \mathrm{C}$ for $5 \mathrm{~min}$, $25^{\circ} \mathrm{C}$ for $5 \mathrm{~min}$ and $36^{\circ} \mathrm{C}$ for $60 \mathrm{~min}$.

\section{Visualization of enzyme products}

To visualize products at each step, reaction mixtures were dried in a vacuum concentrator after phenolchloroform extraction. The dried reaction mixtures were dissolved in loading buffer $(80 \%$ formamide, $0.1 \%$ xylene cyanol and $0.1 \%$ bromophenol blue) and the products were separated in $8 \mathrm{M}$ urea-denaturing $20 \%$ polyacrylamide gels at $2,000 \mathrm{~V}$ for $3 \mathrm{~h}$. Gels were 
autoradiographed with X-Omat film (Kodak).

\section{Results}

Trimming of 3 ' terminal phosphate at the gap

In the early purification step of Fpg, we observed two cleavage products of the substrate DNA. By treatment of the substrate DNA with the AS 40/100 fraction, two cleavage products, the lower and the upper band were observed (Figure 1, lane 4). The lower band co-migrated with the nicked fragment of substrate DNA treated with purified Fpg (lane 3) or hot piperidine (lane 1), while the upper band was located at the same position as synthetic 12 mer without the 3 ' terminal phosphate group (lane 5 ). Thus, we hypothesized that certain kinds of $3^{\prime}$ phosphatases in the AS 40/100 fraction might remove the $3^{\prime}$ terminal phosphate group from the gap site after the action of Fpg.

To confirm this idea, the AS 40/100 fraction was incubated after the substrate DNA was completely cleaved at the 8-oxo-G site by Fpg. After complete cleavage by Fpg (lane 6), the lower band was shifted to the upper position by the AS 40/100 fraction (lane 7, 8 and 9). After $90 \mathrm{~min}$, the lower band almost completely shifted to the upper position (lane 9), which indicates that $3^{\prime}$ phosphatases in the AS 40/100 fraction remove $3^{\prime}$ terminal phosphate after the removal of 8-oxo-G and the resulting AP site by Fpg.

\section{Cleavage site $3^{\prime}$ to 8-0xo-G}

For determination of cleavage site $3^{\prime}$ to $8-0 \times 0-G$ by Fpg or the AS 40/100 fraction, 3' end-labeled substrate

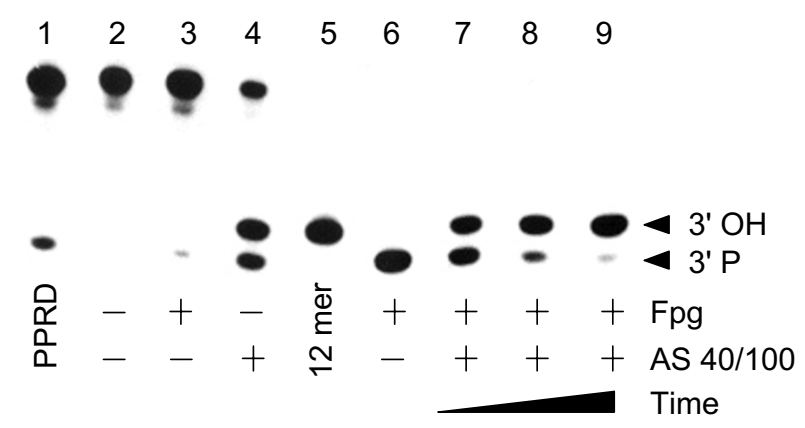

Figure. 1. Trimming of $3^{\prime}$ terminal phosphate by the AS 40/100 fraction after the removal of the 8-0xo-G and AP sites from $5^{\prime}$ end-labeled 21-mer substrate DNA by Fpg. Lane 1, treated with piperidine at $90^{\circ} \mathrm{C}$ for $30 \mathrm{~min}$; lane 2, incubated without enzymes; lane 3 , incubated with 400 units of $\mathrm{Fpg}$ at $25^{\circ} \mathrm{C}$, for $5 \mathrm{~min}$; lane 4 , incubated with $400 \mathrm{mg}$ of AS $40 / 100$ fraction for $60 \mathrm{~min}$; lane 5 , synthetic 12 mer; lane 6, incubated with 400 units of Fpg for 90 min; lane 7, 8 and 9 treated with $200 \mu \mathrm{g}$ of AS 40/100 fraction for 10, 60 and 90 min, respectively, after incubation with 400 units of Fpg for $90 \mathrm{~min}$.
DNA was incubated with either Fpg or the AS 40/100 fraction. The nicked product by Fpg (Figure 2, lane 2) co-migrated with the fragment produced by hot piperidine (lane 4), which was known to result in the $5^{\prime}$ terminal phosphate at the gap (Chung et al., 1992). While two products of $5^{\prime}$ end-labeled DNA were formed by the AS 40/100 fraction, only one cleaved fragment of 3 ' end-labeled DNA by the AS 40/100 fraction was observed at the same position as the fragments produced by Fpg or hot piperidine (lane 3). Thus, Fpg or the AS 40/100 fraction did not remove 5 ' terminal phosphate at the gap.

\section{Filling the gap produced by Fpg}

The above results indicated that Fpg formed one nucleotide gap with $3^{\prime}$ and $5^{\prime}$ terminal phosphate at the site of 8-oxo-G, and that $3^{\prime}$ phosphatases in the AS $40 / 100$ fraction then removed the $3^{\prime}$ terminal phosphate, thus resulting in one nucleotide gap adequate for the insertion of dGTP. We then tried to complete the BER synthesis by filling the gap (Figure 3). After complete cleavage of substrate DNA by Fpg (lane 1) and successive removal of $3^{\prime}$ terminal phosphate by the AS 40/100 fraction (lane 2), the gap was completely filled and the nick was sealed by T4 DNA polymerase, 4 dNTPs, and T4 DNA ligase (lane 4). However, no gap filling was observed without the removal of 3' phosphate by the AS 40/100 fraction (lane 3) or without 4 dNTPs (lane 5).

When only one nucleotide was used, dGTP was selectively inserted into the gap (Figure 4, lane 4). In the case of dATP, dCTP or dTTP, the gap was not filled and the DNA was degraded (lane 1,2 and 3 , respectively). With dATP, dCTP and dTTP, some

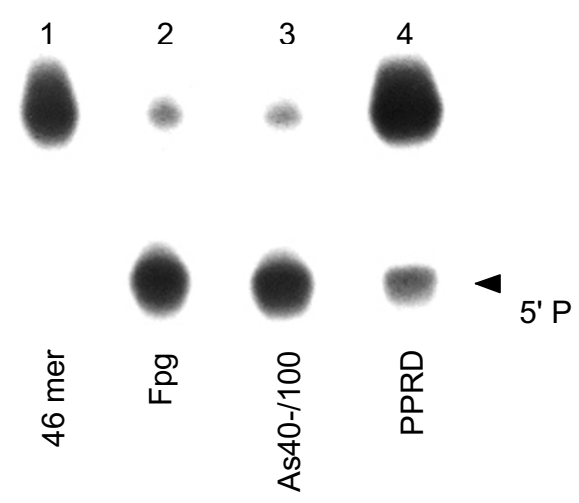

Figure 2. Cleavage of 3 ' end-labeled 46-mer substrate DNA by Fpg or the AS 40/100 fraction. Lane 1, incubated without enzymes; lane 2, incubated with 200 units of $\mathrm{Fpg}$ at $25^{\circ} \mathrm{C}$, for $60 \mathrm{~min}$; lane 3, 200 $\mu \mathrm{g}$ of AS 40/100 fraction for $60 \mathrm{~min}$; lane 4, treated with piperidine at $90^{\circ} \mathrm{C}$ for $30 \mathrm{~min}$. 


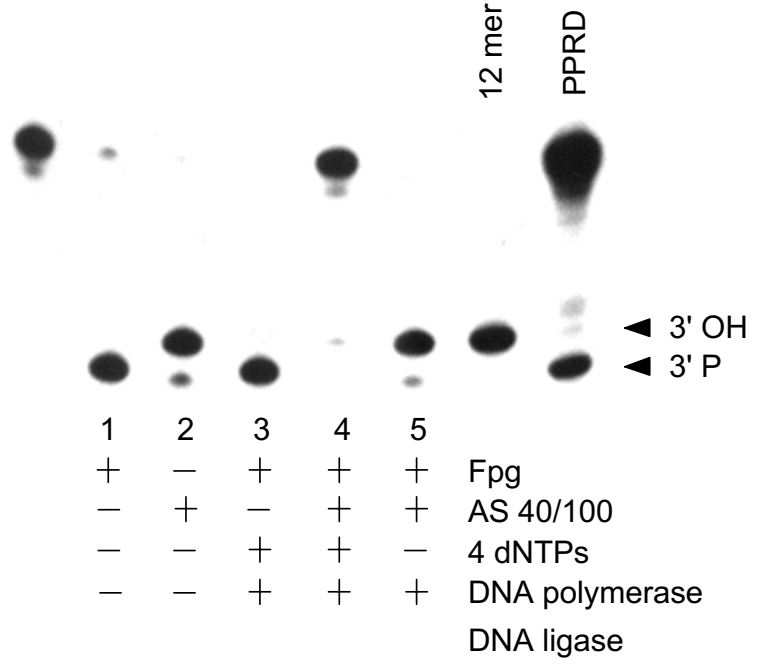

Figure 3. Essential requirements for the trimming of $3^{\prime}$ terminal phosphate for filling the gap in $5^{\prime}$ end-labeled 21-mer substrate DNA generated by Fpg. Lane 1, incubated with 400 units of Fpg for 90 min; lane 2, incubated with 400 units of Fpg for 90 min and 200 $\mu \mathrm{g}$ of AS 40/100 fraction for $90 \mathrm{~min}$; lane 3, gap filling in the presence of T4 DNA polymerase, 4 dNTPs and T4 DNA ligase without treatment of AS 40/100 fraction after incubation with Fpg; lane 4, gap filling after treatment of Fpg followed by incubation with AS 40/100 fraction; lane 5, gap filling without 4 dNTPs; lane 21-mer, no treatment; lane 12-mer, synthetic 12-mer having no $3^{\prime}$ terminal phosphate; lane PPRD, single-stranded 21-mer treated with hot piperidine.

misincorporation was observed (lane 5). Laddering in lane 4 might be due to the $3^{\prime}$ to $5^{\prime}$ exonuclease activity of T4 DNA polymerase in the presence of only a subset of 4 dNTPs (Tabor et al., 1987).

\section{Discussion}

In the present study, the BER synthesis of DNA containing 8-0xo-G is demonstrated in vitro, according to the scheme (Figure 5). Initially, Fpg initiates BER synthesis by generating a single nucleotide gap through its 8-oxo-G glycosylase/AP lyase activity. Then, 3'phosphatases in the AS 40/100 fraction trim the $3^{\prime}$ terminal phosphate off to prime DNA synthesis. Finally, DNA ligase and DNA polymerase complete the repair synthesis.

Fpg is a DNA glycosylase to remove Fapy as well as 8-oxo-G from DNA (Tchou et al., 1991). In addition to glycosylase activity, Fpg has other DNA repair activities; AP lyase (Tchou et al., 1991) and 5' dRPase (Graves et al., 1992). 8-oxo-G glycosylases (OGG1), functionally homologous to Fpg, have been found and cloned in eukaryotic cells including Saccharomyces (van der Kemp et al., 1996), mouse (Rosenquist et al., 1997) and human (Aburatani et al., 1997; Radicella et al., 1997). Fpg and the eukaryotic DNA repair

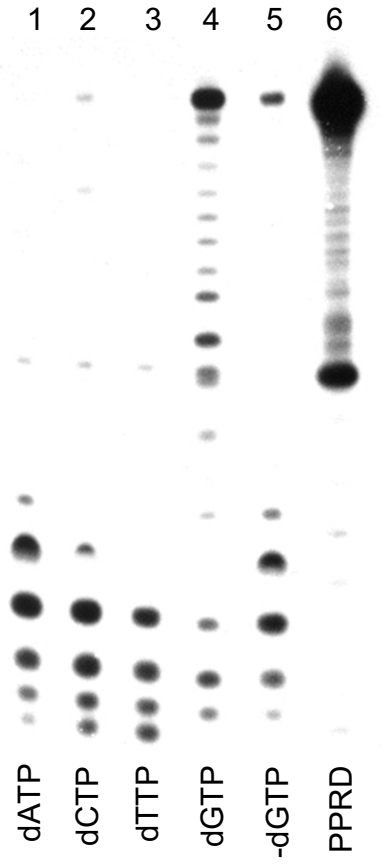

Figure 4. Selective insertion of dGTP to the gap. After treatment of $5^{\prime}$ end-labeled 21-mer substrate DNA with Fpg and AS 40/100 fraction, the gapped DNA was incubated with dATP (lane 1), dCTP (lane 2), dTTP (lane 3), dGTP (lane 4) or dNTPs except dGTP (lane 5) in the presence of T4 DNA polymerase, 4 dNTPs and T4 DNA ligase. Lane 6 indicates substrate DNA treated with hot piperidine.

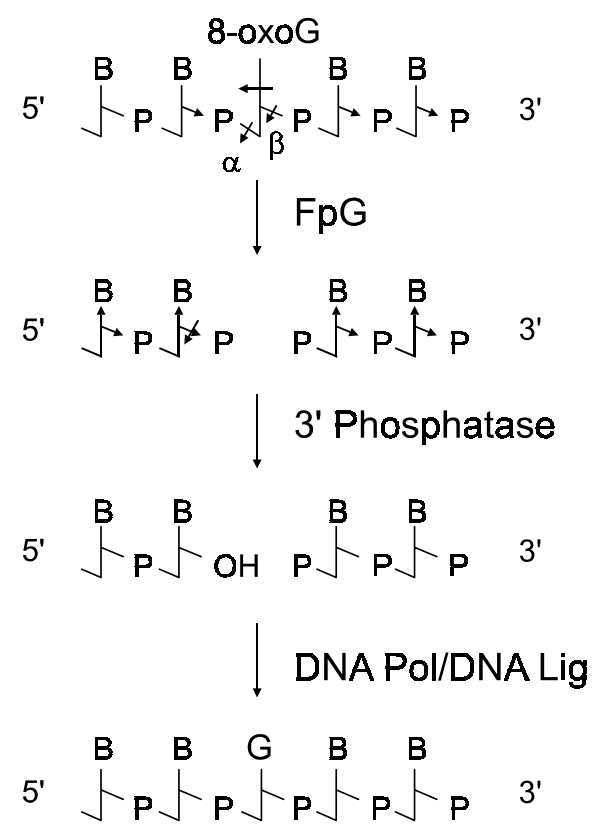

Figure 5. Schematic base excision repair synthesis of DNA containing 8-oxo-G in Escherichia coli. 
enzymes are known to possess AP lyase activity ( $N$ glycosylase/AP lyase) and these enzymes are suggested to remove 8-oxo-G through the formation of Schiff base with 8-oxo-G (McCullough et al., 1999; Fedorova et al., 2002; Fromme et al., 2003). Fpg encounters 8-oxo-G in DNA by processive search (DNA sliding) rather than distributive search (random-diffusion-mediated) (Francis and David, 2003). Fpg form a specific complex, a Schiff base intermediate, with 8-oxo-G in DNA through interaction between a lysine residue (Lys249) of Fpg and 8-oxo-G. 8-0xo-G is removed from the DNA strand, and the one nucleotide gap is formed through $\beta$-elimination followed by $\delta$ elimination.

While Fpg removes the AP site through $\beta, \delta$-elimination mechanisms after removal of 8-oxo-G (Bhagwat and Gerlt, 1996), yeast OGG1 was suggested to remove the sugar moiety as trans-4-hydroxy-2-pental5 -phosphate via possible hydrolysis in the presence of $\mathrm{Mg}^{2+}$ (Sandigursky et al., 1997). In contrast, mouse OGG1 elicits only $\beta$-elimination resulting in 3 '-terminal $\alpha, \beta$-unsaturated sugar that must be processed for gap filling (Rosenquist et al., 1997; Zharkov et al., 2000). Therefore, $3^{\prime}$ diesterase may be necessary to trim the 3 ' terminus for DNA polb, XRCC1 and DNA ligase to complete the short patch BER repair synthesis (Memisoglu and Samson, 2000). Recently, Pascucci et al. (2002) showed reconstitution of the BER repair synthesis for 8-0xo-G with purified human OGG1. In the experiment, 3'-terminal sugar phosphate was removed by human AP endonuclease1 (HAP1) containing $3^{\prime}$ diesterase activity, and Pol $\beta$ and DNA ligase I completed repair synthesis.

Our results showed that $3^{\prime}$ phosphatase activity in the AS 40/100 fraction trimmed 3' terminal phosphate at the gap. In DNA repair synthesis, exonuclease III (Xth, Henner et al., 1983) or endonuclease IV (Nfo, Bailly and Verly, 1989) might remove $3^{\prime}$ terminal phosphate to prime the DNA synthesis. In this study, endonuclease IV might remove $3^{\prime}$ terminal phosphate, because we used an exonuclease III-deficient strain of $E$. coli. With in vitro reconstitution system, endonuclease IV in concert with Fpg generated one nucleotide gap to prime DNA synthesis (Harrison et al., 1999). However, involvement of exonuclease III cannot be excluded in BER synthesis because both $x$ th and nfo mutants, but not xth/nfo double mutant, could carry out complete repair of DNA strand breaks mediated by Fpg when treated with hydrogen peroxide (Galhardo et al., 2000).

Even though BER DNA synthesis by Fpg is suggested to be a major mechanism of 8-oxo-G repair, other mechanisms including nucleotide excision repair have been proposed to backup BER in $E$. coli, because of the strong miscoding property of 8-oxo-G. Nucleotide excision repair (NER) by UvrABC endonu- clease was suggested to be a candidate for the repair of 8-oxo-G (Czeczot et al., 1991). However, it was recently reported that the frequency of $\mathrm{GC}$ to $\mathrm{TA}$ mutation induced by $\gamma$-radiation is greater in the $\mathrm{fpg}^{-}$ strain than the fpguvrA double mutant of $E$. coli. This implies that NER may not act as a correct backup system, but is responsible for making mistakes leading to mutation (Kuipers et al., 2000). Another possible candidate is a newly found $8-0 \times 0-G$ glycosylase (Nei) that is identical to endonuclease VIII and is considered as $E$. coli homologue of mammalian OGG2 (Hazra et al., 2000). While Fpg did not excise 8-oxo$G$ efficiently when paired with a Nei excised 8-oxo-G in 8-oxo-G:A and in 8-oxo-G:C pair to a similar degree. Thus, Nei can backup Fpg by repairing 8-oxo$\mathrm{G}: \mathrm{C}$ in addition to 8-oxo-G:A. Nei shares the N-terminal amino acids of Fpg, especially, the N-terminal Pro, which is considered as an active site of Fpg in terms of 8-oxo-G glycosylase/AP lyase activity (McCullough et al., 1999). Recently, MutH, one member of methyldirected mismatch repair system of $E$. coli was reported to be involved in repair of $8-0 \times 0-G$ in DNA, even though it was not demonstrated whether it remove directly 8-oxo-G, adenine misincorporated opposite 8-oxo-G or both (Wyrzykowski and Volkert, 2003).

Like E. coli, several repair pathways have been proposed in humans. Involvement of human NER and long patch ( 3 to 4 nucleotides) BER in the repair of 8-oxo-G has been demonstrated (Jaiswal et al., 1998). Contrastingly, the preferential repair of $8-0 x 0-G$ by short patch BER was demonstrated with HeLa cell extracts and circular DNA containing a single 8-0xo-G (Fortini et al., 1999). In addition to core components of 8-oxo-G BER synthesis including OGG1, HAP, DNA polymerase and DNA ligase, xeroderma pigmentosum G (XPG), Cockayne syndrome B (CSB) and TFIIH (Le Page et al., 2000a), or BRCA1 and BRCA2 (Le Page et al, 2000b) were reported to be required or necessary in transcription-coupled repair of 8-oxo-G. In contrast, Poly (ADP-ribose) polymerase1 was required for completing repair synthesis of nontranscribed strand (Le Page et al., 2003). So, machinery for repair synthesis of 8-oxo-G-containing DNA in mammalian cells may be much more complicated and differently act in a transcription- and/or replication-dependent manner. Therefore, contribution of several repair pathways under different situations should be understood in the context of physiologic and pathologic significance.

\section{Acknowledgement}

The authors thank Dr. Kasai at the University of Occupational and Environmental Health, Japan for the gift of oligonucleotides containing 8-oxo-G. 


\section{References}

Aburatani H, Hippo Y, Ishida T, Takashima R, Matsuba C, Kodama T, Takao M, Yasui A, Yamamoto K, Asano M, Fukasawa K, Yoshinari T, Inoue H, Ohtsuka E, Nishimura $\mathrm{S}$. Cloning and characterization of mammalian 8-hydroxyguanine-specific DNA glycosylase/apurinic, apyrimidinic lyase, a functional mutM homologue. Cancer Res 1997;57:2151-6

Bailly V, Verly WG. The multiple activities of Escherichia coli endonuclease IV and the extreme lability of 5'-terminal base-free deoxyribose 5-phosphates. Biochem J 1989;259: 761-8

Bhagwat M, Gerlt JA. 3'- and 5'-strand cleavage reactions catalyzed by the Fpg protein from Escherichia coli occur via successive $\beta$ - and $\delta$-elimination mechanisms, respectively. Biochemistry 1996;35:659-65

Cheng KC, Cahill DS, Kasai H, Nishimura S, Loeb LA. 8-Hydroxyguanine, an abundant form of oxidative DNA damage, causes $\mathrm{G} \rightarrow T$ and $A \rightarrow C$ substitutions. J Biol Chem 1992;267:166-72

Chung $M H$, Kasai $H$, Jones DS, Inoue $H$, Ishikawa $H$, Ohtsuka E, Nishimura S. An endonuclease activity of Escherichia coli that specifically removes 8-hydroxyguanine residues from DNA. Mutat Res 1991;254:1-12

Chung $M H$, Kiyosawa $H$, Ohtsuka E, Nishimura S, Kasai $H$. DNA strand cleavage at 8-hydroxyguanine residues by hot piperidine treatment. Biochem Biophys Res Commun 1992; 188:1-7

Czeczot H, Tudek B, Lambert B, Laval J, Boiteux S. Escherichia coli Fpg protein and UvrABC endonuclease repair DNA damage induced by methylene blue plus visible light in vivo and in vitro. J Bacteriol 1991;173:3419-24

Fedorova OS, Nevinsky GA, Koval VV, Ishchenko AA, Vasilenko NL, Douglas KT. Stopped-flow kinetic studies of the interaction between Escherichia coli Fpg protein and DNA substrates. Biochemistry 2002;41:1520-8

Fortini P, Parlanti E, Sidorkina OM, Laval J, Dogliotti E. The type of DNA glycosylase determines the base excision repair pathway in mammalian cells. J Biol Chem 1999;274:15230-6

Francis AW, David SS. Escherichia coli MutY and Fpg Utilize a Processive Mechanism for Target Location. Biochemistry 2003;42:801-10

Fromme JC, Bruner SD, Yang W, Karplus M, Verdine GL. Product-assisted catalysis in base-excision DNA repair. Nat Struct Biol 2003;10:204-11

Galhardo RS, Almeida CE, Leito AC, Cabral-Neto JB. Repair of DNA lesions induced by hydrogen peroxide in the presence of iron chelators in Escherichia coli: participation of Endonuclease IV and Fpg. J Bacteriol 2000;182:1964-8

Graves RJ, Felzenszwalb I, Laval J, O'Connor TR. Excision of $5^{\prime}$-terminal deoxyribose phosphate from damaged DNA is catalyzed by the Fpg protein of Escherichia coli. J Biol Chem 1992;267:14429-35

Grollman AP, Moriya M. Mutagenesis by 8-oxoguanine:an enemy within. Trends Genet 1993;9:246-9

Harrison L, Hatahet Z, Wallace SS. In vitro repair of synthetic ionizing radiation-induced multiply damaged DNA sites. J Mol Biol 1999;290:667-84

Hazra TK, Izumi T, Venkataraman R, Kow YW, Dizdaroglu $M$, Mitra S. Characterization of a novel 8-oxoguanine-DNA glycosylase activity in Escherichia coli and identification of the enzyme as endonuclease VIII. J Biol Chem 2000;275: 27762-7

Henner WD, Grunberg SM, Haseltine WA. Enzyme action at $3^{\prime}$ termini of ionizing radiation-induced DNA strand breaks. J Biol Chem 1983;258:15198-205

Jaiswal M, Lipinski LJ, Bohr VA, Mazur SJ. Efficient in vitro repair of 7-hydro-8-oxodeoxyguanosine by human cell extracts: involvement of multiple pathways. Nucleic Acids Res 1998;26:2184-91

Kasai $\mathrm{H}$, Nishimura S. Hydroxylation of deoxyguanosine at the C-8 position by ascorbic acid and other reducing agents. Nucleic Acids Res 1984;12:2137-45

Kuipers GK, Slotman BJ, Poldervaart HA, van Vilsteren IM, Reitsma-Wijker CA, Lafleur MV. The role of nucleotide excision repair of Escherichia coli in repair of spontaneous and gamma-radiation-induced DNA damage in the lacZ $\alpha$ gene. Mutat Res 2000;460:117-25

Le Page F, Kwoh EE, Avrutskaya A, Gentil A, Leadon SA, Sarasin A, Cooper PK. Transcription-coupled repair of 8oxoguanine: requirement for XPG, TFIIH, and CSB and implications for Cockayne syndrome. Cell 2000a;101:159-71

Le Page F, Randrianarison V, Marot D, Cabannes J, Perricaudet $M$, Feunteun J, Sarasin A. BRCA1 and BRCA2 are necessary for the transcription-coupled repair of the oxidative 8 -oxoguanine lesion in human cells. Cancer Res 2000b;60: 5548-552

Le Page F, Schreiber V, Dherin C, De Murcia G, Boiteux S. Poly(ADP-ribose) polymerase-1(PARP-1) is required in murine cell lines for base excision repair of oxidative DNA damage in absence of DNA polymerase beta. J Biol Chem; in press

McCullough AK, Dodson ML, Lloyd RS. Initiation of base excision repair: glycosylase mechanisms and structures. Annu Rev Biochem 1999;68:255-85

Memisoglu A, Samson L. Base excision repair in yeast and mammals. Mutat Res 2000;451:39-51

Michaels ML, Miller JH. The GO system protects organisms from the mutagenic effect of the spontaneous lesion 8hydroxyguanine (7,8-dihydro-8-oxoguanine). J Bacteriol 1992; $174: 6321-5$

Pascucci B, Maga G, Hubscher U, Bjoras M, Seeberg E, Hickson ID, Villani G, Giordano C, Cellai L, Dogliotti E. Reconstitution of the base excision repair pathway for 7,8dihydro-8-oxoguanine with purified human proteins. Nucleic Acids Res 2002;30:2124-30

Radicella JP, Dherin C, Desmaze C, Fox MS, Boiteux S. Cloning and characterization of hOGG1, a human homolog of the OGG1 gene of Saccharomyces cerevisiae. Proc Natl Acad Sci USA 1997:94:8010-5

Rosenquist TA, Zharkov DO, Grollman AP. Cloning and characterization of a mammalian 8-oxoguanine DNA glycosylase. Proc Natl Acad Sci USA 1997;94:7429-34 
Sandigursky M, Yacoub A, Kelley MR, Xu Y, Franklin WA, Deutsch WA. The yeast 8-oxoguanine DNA glycosylase (Ogg1) contains a DNA deoxyribophosphodiesterase (dRpase) activity. Nucleic Acids Res 1997;25:4557-61

Shibutani S, Takeshita M, Grollman AP. Insertion of specific bases during DNA synthesis past the oxidation-damaged base 8-oxodG. Nature 1991;349:431-4

Tabor S, Struhl K. DNA-dependent DNA polymerase. In Current Protocols in Molecular Biology (Ausbel FM, Brent R, Kingston RE, Moore DD, Seidman JG, Smith JA, Struhl K, eds), 1987, 3.5.10, Wiley, New York, NY.

Tchou J, Kasai H, Shibutani S, Chung MH, Laval J, Grollman AP, Nishimura S. 8-oxoguanine (8-hydroxyguanine) DNA glycosylase and its substrate specificity. Proc Natl Acad Sci
USA $1991 ; 88: 4690-4$

van der Kemp PA, Thomas D, Barbey R, de Oliveira R, Boiteux S. Cloning and expression in Escherichia coli of the OGG1 gene of Saccharomyces cerevisiae, which codes for a DNA glycosylase that excises 7,8-dihydro-8-oxoguanine and 2,6-diamino-4-hydroxy-5-N-methylformamidopyrimidine. Proc Natl Acad Sci USA 1996;93:5197-202

Wyrzykowski J, Volkert MR. The Escherichia coli methyldirected mismatch repair system repairs base pairs containing oxidative lesions. J Bacteriol 2003;185:1701-4

Zharkov DO, Rosenquist TA, Gerchman SE, Grollman AP. Substrate specificity and reaction mechanism of murine 8oxoguanine-DNA glycosylase. J Biol Chem 2000;275:2860717 